\title{
Forage yield and nitrogen nutrition dynamics of warm-season native forage genotypes under two shading levels and in full sunlight
}

\author{
Raquel Santiago Barro ${ }^{1}$, Alexandre Costa Varella ${ }^{2}$, Gilles Lemaire ${ }^{3}$, Renato Borges de \\ Medeiros $^{4}$, João Carlos de Saibro ${ }^{4}$, Carlos Nabinger ${ }^{4}$, Felipe Villamil Bangel ${ }^{4}$, Igor Justin \\ Carassai $^{4}$
}

\footnotetext{
1 Programa de Pós-Graduação em Zootecnia/Universidade Federal do Rio Grande do Sul (UFRGS). Bolsista CAPES

2 EMBRAPA Pecuária Sul e Centro Nacional de Pesquisa de Ovinos, Bagé, RS.

3 Professor Visitante no Programa de Pós-Graduação em Zootecnia/UFRGS, PVE - CAPES.

${ }^{4}$ Departamento de Plantas Forrageiras e Agrometeorologia/UFRGS.
}

\begin{abstract}
The successful achievement of a highly productive understorey pasture in silvopastoral systems depends on the use of well-adapted forage genotypes, showing good agronomic performance and persistence under shading and grazing. In this study, the herbage dry matter yield (DMY) and nitrogen nutrition dynamics were determined in three native warmseason grasses (Paspalum regnellii, Paspalum dilatatum and Paspalum notatum) and a forage legume (Arachis pintoi) under two shading levels compared with full sun. The experiment was conducted in the Campanha region, Bagé, state of Rio Grande do Sul, Brazil, during two evaluation cycles (2008/2009 and 2009/2010). Three shade cloth levels (0\%, 50\% and 80\% of ligh restriction) were applied to the forage genotypes in a split plot design, in which shading levels were the main plot and forage genotypes were the subplots, with three replications. P. regnellii showed the highest accumulated DMY (1500 and $1700 \mathrm{~g} \mathrm{~m}^{-2}$, respectively, for the first and second evaluation cycles) at all shading levels and showed no DMY decreased under the heavy shade (80\%). Average DMY over the four genotypes under the 50\% shade level was higher or equal compared with full sun. Influence of rainfall was observed on the DMY performance of all genotypes: the positive effect of moderate shading (50\%) on P. dilatatum and P. notatum DMY was associated to a low soil water availability status. Increased shading level resulted in high nitrogen nutrition index values on grasses, in comparison with full sun. All genotypes performed well under the moderate shading level, but the DMY of both $P$. regnellii and $P$. dilatatum and the herbage $\mathrm{N}$ content in $P$. notatum and A. pintoi of all genotypes stood out, showing that those main genotypes are promising to grow in silvopastoral systems at the Campanha region in southern Brazil.
\end{abstract}

Key Words: Arachis pintoi, artificial shade, nitrogen status, Paspalum sp., silvopastoral system, warm-season pasture

\section{Introduction}

In sustainable silvopastoral systems, the success of the integration of herbaceous and woody components depends on the use of forage genotypes well adapted to this condition, showing good yield performance and persistence under shade. Due to the economic and environmental importance, some native forage grass genotypes from the Pampa and the Atlantic Forest biomes, such as Paspalum dilatatum and Paspalum notatum, have been more intensively studied at full sun under extensive grazing conditions (Valls et al., 2009) than under shading conditions. However, it is well known that there is evidence of great genetic variability within native forage species, particularly with the perennial warm-season grasses, regarding their potential yield under shade in southern Brazil (Saibro, 2001; Varella et al., 2009; Soares et al., 2009; Barro et al., 2010).
Nevertheless, there is still a lack of local research aiming at evaluating the agronomic and physiological responses of the native grasses under shade. Therefore, it is important to study the multiple physiological relationships of forages under different light levels and to select shade-tolerant genotypes to encourage farmers to apply sustainable land use systems in Southern Brazil (Saibro, 2001).

Under the subtropical conditions of Southern Brazil, $P$. notatum and $P$. dilatatum species have high frequency in the native grasslands and are well recognized as well productive with highly nutritive forages (Valls et al., 2009), whereas Paspalum regnellii and Arachis pintoi are more important native forages in the Brazilian tropical regions (Ramos et al., 2010).

Shade may modify the nitrogen nutrition dynamics of forage plants (Wilson \& Wong, 1982; Cruz et al., 1995). Many hypotheses have been proposed to explain the positive effects of shading on the forage $\mathrm{N}$ content of 
grasses. Overall, the improvement of nitrogen nutrition of plants under shade is attributed to a greater mineralization of the soil organic matter, because of better soil thermal conditions and water status, fostering the action of nitrifying microorganisms or because of the reduction of biomass production under shade, which may result in greater concentration of $\mathrm{N}$ in plant compared with full sun (Wilson et al., 1990). Thus, there is an important issue concerning the nutritional value of forage under shade, which may be explained by studying the plant nitrogen dynamics, compared with full sunlight.

The objective of this study was to determine the forage yield of three perennial native grasses ( $P$. notatum, $P$. regnellii, $P$. dilatatum) and a legume (A. pintoi) under two artificial shading levels (50\% and $80 \%$ shade cloth) and at full sun and its relation to the plant nitrogen nutritional status under the subtropical conditions of southern Brazil over two years.

\section{Material and Methods}

The experiment was conducted over two years at Embrapa Pecuária Sul e Centro Nacional de Pesquisa de Ovinos, in Bagé, Rio Grande do Sul State (31⒉21'09"S and $\left.54^{\circ} 01^{\prime} 00^{\prime \prime} \mathrm{W}\right)$. The climate is classified as a cold subtropical with frequent frost events in the winter and a warm summer. Mean annual temperature is $17.9^{\circ} \mathrm{C}$, reaching a maximum of $30.5^{\circ} \mathrm{C}$ in January and a minimum of $8.7^{\circ} \mathrm{C}$ in June. Mean total annual rainfall is $1300 \mathrm{~mm}$ and heavy rains and frosts can occur from April to November. On average, between November and May, dry periods with rainfall deficits of about $100 \mathrm{~mm}$ may occur at seven to every ten years, and rainfall deficits may be more than $300 \mathrm{~mm}$ at once to every ten years (Ramos et al., 2009).

The soil at the experimental area is classified as a Planosol, with clay content ranging from 14 to 23\%, lightly acid (mean pH of 5.2) and shows low levels of available phosphorus (7 to $13 \mathrm{mg} / \mathrm{dm}^{3}$ ). Other soil characteristics include: available $\mathrm{K}=56 \mathrm{mg} / \mathrm{dm}^{3}$, organic matter $=2.1 \%$, $\mathrm{Ca}=4.3 \mathrm{cmol}_{\mathrm{c}} / \mathrm{dm}^{3}$, exchangeable $\mathrm{Al}=0.4 \mathrm{cmol}_{c} / \mathrm{dm}^{3}$, and exchangeable $\mathrm{Mg}=1.3 \mathrm{cmol}_{\mathrm{c}} / \mathrm{dm}^{3}$. The total soil cation exchange capacity (CEC) at base saturation occurs at 51\% and of $\mathrm{Al}$ at $6.5 \%$.

The experimental area was established in 2005. In November, the area received an uniform amount of nine $\mathrm{t} / \mathrm{ha}$ of limestone, having both the lime and fertilizer doses calculated after soil analysis at $0-20 \mathrm{~cm}$ depth, according to recommendations of the Brazilian Soil Science Society (SBCS, 2004) for forage species. Plant genotypes were previously propagated in a greenhouse and transplanted to field plots in December 2005, using an equal number of seedlings per genotype per experimental unit.

Shading treatments were applied by using black polypropylene clothes, with two different mesh sizes, corresponding to a mean of $50 \%$ and $80 \%$ reduction of the photosynthetically active radiation (PAR) compared with full sun. Shade clothes were built on woody structures similar to greenhouses and positioned at northeastsouthwest orientation.

Treatments consisted of three shading levels ( $0 \%, 50 \%$ and $80 \%$ light restriction) and four forage genotypes: Paspalum regnellii access BRA-007382 (Embrapa Cenargen), Paspalum notatum ecotype André da Rocha, Paspalum dilatatum ecotype Virasoro and Arachis pintoi ecotype hybrid AGK12787 vs NC1579(Embrapa Cenargen), arranged in a split plot design with three replications.

From 2005 to 2008, this area was fertilized with $100 \mathrm{~kg} / \mathrm{ha}$ $\mathrm{N}, 80 \mathrm{~kg} / \mathrm{ha} \mathrm{P}_{2} \mathrm{O}_{5}$ and $60 \mathrm{~kg} / \mathrm{ha}$ of $\mathrm{K}_{2} \mathrm{O}$ annually. Total soil nitrogen fertilizer was split into three equal applications in January, February and March, immediately after harvesting the samples. The legume did not receive any mineral nitrogen fertilizer.

The study was conducted in two evaluation cycles: from November 2008 to April 2009 and from October 2009 to April 2010. At the beginning of each cycle (11/06/08 and 10/15/09), a standardization cut was proceeded to all plots. Afterwards, samples were harvested at intervals of approximately 30 days. The experimental units, with an area of $2.0 \mathrm{~m}^{2}$ each $(1 \times 2 \mathrm{~m})$, were divided into five randomly determined strips $(0.25 \times 2.0 \mathrm{~m})$. Then, plot sampling was accomplished by harvesting plants within each strip, monthly. This sampling methodology allowed the determination of the cumulative forage yield at different growing stages over the two evaluation cycles.

Forage dry matter yield (DMY) was calculated from samples collected in a $625 \mathrm{~cm}^{2}$ quadrat on each experimental unit. Cutting heights were established according to the growth habit of each genotype: for $P$. notatum, the cutting height was $10 \mathrm{~cm}$ above soil level; $15 \mathrm{~cm}$ for $P$. regnellii and $P$. dilatatum (tall tussock-type plant); and $2 \mathrm{~cm}$ for $A$. pintoi (prostrate stoloniferous plant). Forage samples were dried at $65{ }^{\circ} \mathrm{C}$ and the biomass dry weight per quadrat was extrapolated to dry matter yield per square meter $\left(\mathrm{g} / \mathrm{m}^{2}\right)$.

Forage total N content was determined by the Kjeldahl method (AOAC, 1975) at the Laboratory of Embrapa. Estimates of the critical $\mathrm{N}$ level in the forage were performed using the equations developed by Lemaire \& Gastal (1997): $\mathrm{N}=\mathrm{a}^{\prime}(\mathrm{W})^{1-\mathrm{b}}$; in which: a' was the $\mathrm{N}$ uptake by the forage 
( $\mathrm{kg} / \mathrm{ha}$ ); W was the forage mass (t/ha DM); and 1- b was the alometric relationship, that expressed the ratio between the relative $\mathrm{N}$ uptake rate and the relative growth rate of the forage. Thus, to determine the critical N level within biomass, two equations were applied according to photosynthetic pathway of $\mathrm{CO}_{2}$ assimilation by plants: (a) $\mathrm{C} 4$ plants: critical $\mathrm{N}=3.6 \times\left(\mathrm{W}^{-0.34}\right)$; (b) C3 plants: critical $\mathrm{N}=4.8 \times\left(\mathrm{W}^{-0.32}\right)$, in which the critical $\mathrm{N}$ level represented the minimum absorption of $\mathrm{N}$ required to achieve the maximum accumulation of dry matter, expressed as \% of $\mathrm{N}$.

The nitrogen nutrition index (NNI) was calculated from the ratio between the actual $\mathrm{N}$ level within the aerial biomass (\% $\mathrm{N}$ ) and the critical $\mathrm{N}$ level, as proposed by Lemaire \& Gastal (1997), according to the equation NNI= $(100 \times \mathrm{N} \%) /$ critical N.

The results of DMY and NNI for each genotype were subjected to Analysis of Variance (ANOVA) and the mean effects of treatments were compared by the Tukey's test at $5 \%$ probability level. Statistics were performed using the PROC MIXED feature of SAS (Statistical Analysis System, version 9.2.).

Plant canopy temperature was monitored by copperconstantan thermocouples, placed $50 \mathrm{~cm}$ above the top of canopy. The mean volumetric soil water content was performed by reflectometers (CS616 Water Content Reflectometer-Campbell Scientific, Inc.) placed at $30 \mathrm{~cm}$ soil depth, in the central portion of an experimental unit per treatment (one replicate) over the experimental period and the two evaluation cycles. All sensors were coupled to a datalogger (model CR10X, Campbell Scientific, Logan, USA), which recorded data every 30 seconds and calculated the averages every hour. Mean data of air temperature, global solar radiation and rainfall were collected from an automatic weather station located at experimental field of Embrapa.

\section{Results and Discussion}

The pattern of mean air temperature from December to April was similar, ranging from 18 to $24^{\circ} \mathrm{C}$. However, total rainfall showed contrasting situations between the two cycles: the accumulated rainfall in the first cycle was $470 \mathrm{~mm}$, whereas in the second cycle, it was $1190 \mathrm{~mm}$. In the second cycle, only in November 2009, a total amount of 460-470 mm rainfall was recorded, which was equivalent to the entire accumulated rainfall over the first cycle (Figure 1). Low water supply was predominant, while estimates of evapotranspiration rates (ET) were higher than precipitation, with the greatest deficits observed in November, March and April 2009 (Figure 1). In the second cycle, no water

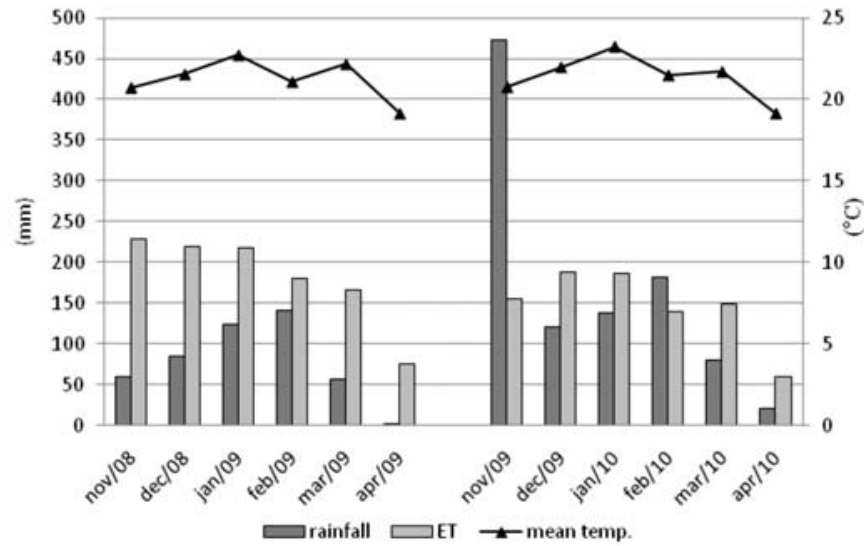

Figure 1 - Total rainfall, mean temperature and reference evapotranspiration rates (ET) for the two evaluation cycles (2008-2009 and 2009-2010) in Bagé, Rio Grande do Sul.

balance deficit was observed. Therefore, in terms of temperature and water relationships, the second evaluation cycle showed more favorable environmental conditions for forage growth than the first cycle.

In both evaluation cycles, forage growth conditions under low light intensity (80\%) reduced forage yield. However, under moderate shading (50\%), plants showed equal or greater DMY compared with full sunlight. In the second cycle, DMY was 37\% higher compared with the first (Table 1), indicating that the highest rainfall observed in the field (Figure 1), might explain the great difference on forage DMY between the two cycles.

There was evidence that air temperature and water availability to plants affected the agronomic performance of genotypes under shade over the two cycles. As a result, in the first cycle, most genotypes showed lower yields at full sunlight than under $50 \%$ shading (Table 1 ) and this was explained by the more favorable microclimate conditions generated by shade cloths. In the second cycle, without water balance deficits, moderate shading had little effect on DMY compared with full sun (Table 1).

In addition, the higher DMY under moderate shading in the first cycle might also be related to the following environmental facts: the measurements of the canopy temperature in full sunlight and under the two shading levels showed an average decrease of $3{ }^{\circ} \mathrm{C}$ in maximum temperatures under shade clothes; the soil moisture content in topsoil $(0-30 \mathrm{~cm})$ showed mean values of 0.24 and $0.41 \mathrm{~cm}^{3} / \mathrm{cm}^{3}$ under full sunlight and under shade clothes, respectively, and this represented a relative increase of about $71 \%$ in the volumetric soil water content under shading compared with open field; and there was evidence that artificial shading promoted a more favorable 
Table 1 - Mean dry matter yield (DMY) of Paspalum regnellii, Paspalum dilatatum, Paspalum notatum and Arachis pintoi grown under full sun ( $0 \%$ shading), moderate (50\% shade) and heavy shading ( $80 \%$ shade), over two evaluation cycles ${ }^{1}$

\begin{tabular}{|c|c|c|c|c|c|c|c|}
\hline \multirow[t]{2}{*}{ Genotype } & \multirow[t]{2}{*}{ Shading level (\%) } & \multicolumn{2}{|c|}{$1^{\text {st }}$ cycle* } & \multicolumn{2}{|c|}{$2^{\text {nd }}$ cycle } & \multicolumn{2}{|c|}{ Mean } \\
\hline & & DMY & SE & DMY & $\mathrm{SE}$ & DMY & SE \\
\hline & & & & \multicolumn{2}{|c|}{$\mathrm{g} / \mathrm{m}^{2}$} & & \\
\hline \multirow{3}{*}{ P. regnellii } & 50 & $900.0 \mathrm{~A}$ & 52.5 & $1417.4 \mathrm{~A}$ & 52.4 & $1158.7 \mathrm{~A}$ & 41.4 \\
\hline & 80 & 809.5A & 53.4 & 1144.4B & 52.4 & $977.0 \mathrm{~B}$ & 41.8 \\
\hline & Mean & $800.4 \mathrm{~b} * * *$ & 30.5 & $1276.2 \mathrm{a}$ & 30.5 & 1038.3 & \\
\hline \multirow{2}{*}{ P. dilatatum } & 80 & $443.7 \mathrm{~B}$ & 57.6 & 836.3B & 53.5 & $640.0 \mathrm{C}$ & 42.9 \\
\hline & Mean & $609.8 b$ & 37.6 & $953.3 \mathrm{a}$ & 36.7 & 781.6 & \\
\hline \multirow[t]{4}{*}{ P. notatum } & 0 & $368.7 \mathrm{AB}$ & 22.89 & 513.6AB & 23.1 & $441.2 \mathrm{~B}$ & 17.4 \\
\hline & 50 & 423.6A & 22.89 & 566.4A & 23.1 & $495.0 \mathrm{~A}$ & 17.4 \\
\hline & 80 & $275.6 B$ & 23.74 & $440.7 \mathrm{~B}$ & 27.7 & $358.2 \mathrm{C}$ & 19.3 \\
\hline & Mean & $356.0 \mathrm{~b}$ & 15.09 & $506.9 a$ & 15.9 & 431.4 & \\
\hline
\end{tabular}

${ }^{1}$ Mean data are resulted from three replications.

$1^{\text {st }}$ cycle - December 2008 to April 2009; $2^{\text {nd }}$ cycle - December 2009 to April 2010.

Means followed by different capital letters in the columns for each genotype differ by Tukey's test at $5 \%$ significance level.

Means followed by different lowercase letters in the lines for each growth cycle differ by Tukey’s test at $5 \%$ significance level.

$\mathrm{SE}$ - mean standard error.

microclimate for forage growth, especially in the first cycle, than in full sun. The consequence was greater DMY observed under moderate shading than in full sun and this was reinforced because evaluations were mainly performed during the spring-summer season, when some periods of drought spells and high temperatures were observed in the experimental area.

These results agreed with those reported by other studies that evaluated forage growth under shade conditions, which reported beneficial effects of moderate shading (40 to $50 \%$ of full sunlight) on forage production, especially under limited soil-moisture content. For example, Gobbi et al. (2009) evaluated the dry matter production of Brachiaria decumbens cv. Basilisk in response to three shading levels (0, 50 and $70 \%)$ over different seasons in the tropical area of Viçosa, Minas Gerais State, Brazil. In this study, the authors observed a linear reduction on forage yield under shade over the rainy season, i.e., a relative DM decrease of 28 and $52 \%$ under 50 and $70 \%$ shading levels, respectively, compared with full sunlight. In the dry season, the authors reported a similar DMY between under the shading levels and in full sunlight. In northern Tanzania, Ludwig et al. (2001) also associated soil water availability to the effect of natural shading of Acacia tortilis trees and found a greater biomass production of forage in full sunlight during the period of high soil water availability than under shade. In contrast, when low soil moisture became limiting during the dry season of tropical savanna, the authors reported a positive effect of shade on forage production, because the water status in plants improved under 55\% light restriction compared with full sun.

In this study, there was a decrease in forage production for most genotypes, when plants were subjected to heavy shading (80\%), except for P. regnellii, which was the only genotype that showed good performance under the high shading level compared with full sun, maintaining the DMY similar to the other treatments (Table 1). This showed that, even under the most favorable microclimatic conditions for growth under $80 \%$ shading, low level of radiation was limiting for most $\mathrm{C} 4$ native type forages, probably because it restricted their cumulative photosynthetic assimilation over the period (Stur, 1991). Under moderate shading, $P$. regnellii showed an increase of $18 \%$ in DMY compared with full sunlight; and mean cumulative DMY of 1500 and $1700 \mathrm{~g} / \mathrm{m}^{2}$ over the three shading levels, for cycles 1 and 2, respectively (Figures 2A and 2B). In general, there is sparse literature information on the DM yield performance of native Paspalum regnellii, particularly under shade conditions (Varella et al., 2009). In another study, Varella et al. (2009) also reported an average DMY of 1800 and $1560 \mathrm{~g} / \mathrm{m}^{2}$ for the same $P$. regnelli genotype grown under 50 and $80 \%$ shading levels, respectively.

Paspalum dilatatum produced, on average, $922 \mathrm{~g} / \mathrm{m}^{2}$ under $50 \%$ shading, which represented an increase of $18 \%$ in DMY compared with that observed under full sun (782 g/m²); under $80 \%$ shading, the DMY decreased by 
$18.2 \%\left(640 \mathrm{~g} / \mathrm{m}^{2}\right)$ compared with full sunlight. In the first evaluation cycle (Figure 2C), the $P$. dilatatum DMY under $50 \%$ shading was higher $(\mathrm{P} \leq 0.05)$ compared with $80 \%$ shading and at full sun; this performance was more evident particularly in February, March and April, when soil moisture was limiting.
In the second cycle, the cumulative DM yield of $P$. dilatatum was higher $(\mathrm{P}<0.05)$ at full sun $(0 \%$ shading $)$ compared with all shaded treatments (Figure 2D). In another study performed in Queensland, Australia, Stur (1991) reported different yield responses of $P$. dilatatum under irrigation and under similar artificial shading levels as the
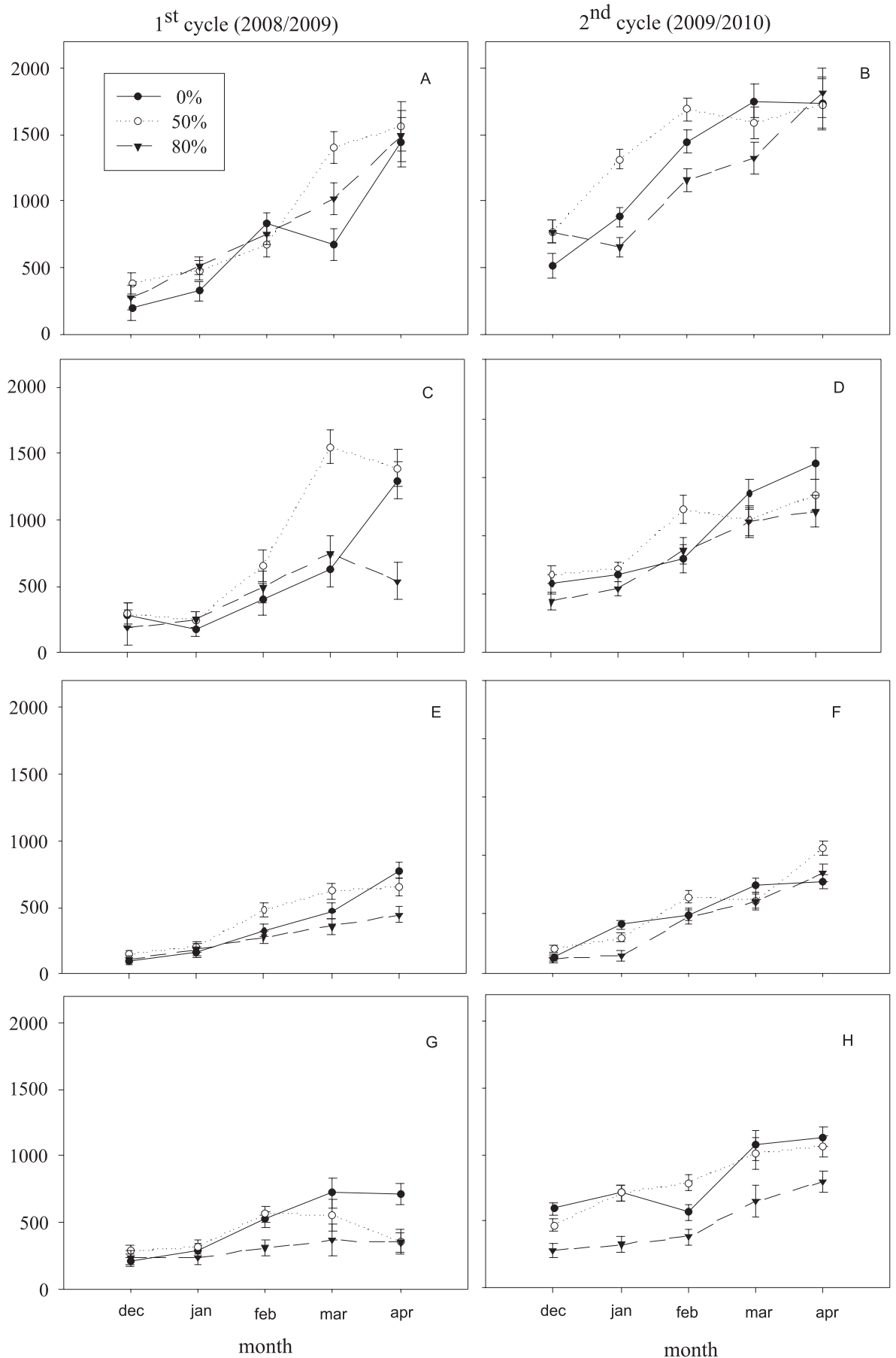

Data are means of three replicates and the bars show the mean standard error for each evaluation. Bagé, Rio Grande do Sul.

Figure 2 - Cumulative DMY of Paspalum regnellii (A and B), Paspalum dilatatum (C and D), Paspalum notatum (E and F) and Arachis pintoi (G and H), over two evaluation cycles (2008/2009 and 2009/2010) and under three shading levels: full sunlight (0\% shade), $50 \%$ and $80 \%$ shade. 
ones applied in this experiment. This author reported that DM yields were similar between plants grown under $50 \%$ shading and in full sun, but under $80 \%$ shade there was a drastic reduction (73\%) in P. dilatatum DM yield compared with full sunlight condition.

Paspalum notatum showed the same pattern of response as $P$. dilatatum under the different shading levels. An increase of $12.2 \%$ was observed in the DMY under moderate shading $\left(495 \mathrm{~g} / \mathrm{m}^{2}\right)$ and a decrease of $18.8 \%$ in heavy shade $\left(358 \mathrm{~g} / \mathrm{m}^{2}\right)$ compared with full sunlight $\left(441 \mathrm{~g} / \mathrm{m}^{2}\right)$ (Table 1). The maximum cumulative DMY of $P$. notatum reached values of 776 and $1065 \mathrm{~g} / \mathrm{m}^{2}$ for the first cycle in full sunlight (Figure 2D) and for the second cycle under moderate shading (Figure 2F), respectively. Paspalum notatum is a well-recognized native forage species in Brazilian grasslands, also showing high potential for silvopastoral systems, often presenting increases on DM yield and on nutritional value under shaded conditions. For instance, Wilson et al. (1990), in southern Queensland, Australia, found an increase of $35 \%$ in the dry matter yield of $P$. notatum under the shade of eucalyptus trees compared with full sun.

Under intense shading (80\%), Arachis pintoi showed a decrease of $40 \%(\mathrm{P} \leq 0.05)$ in DMY compared with full sun. However, under moderate shading (50\%), this legume performance was not affected (Table 1). These results agreed with Gobbi et al. (2009), who reported a 28\% reduction in the DMY of A. pintoi cv. Amarillo under $70 \%$ artificial shading. Andrade \& Valentim (1999) also reported DMY differences in response to shading over the rainy and dry seasons in Central Brazil, for Arachis pintoi, access BRA - 031143. These authors reported a linear decrease on DMY with increasing levels of shade during the rainy season and a linear increase during the dry season. In the present study, A. pintoi did not show DMY differences in response to shade between the two evaluation cycles and this was contrasting with the results achieved by the three other forage species (Figure 1).

In summary, $P$. regnellii showed a high potential of adaptation to heavy shade conditions as for forage DMY. For $P$. dilatatum and $P$. notatum, the positive effects of shade on forage DMY were possibly linked to the low soil water availability. In addition, these two genotypes showed higher yields under moderate shade (50\%) when soil water availability was limiting growth in full sunlight (2008/2009 cycle). A. pintoi showed satisfactory response only under moderate shading level. These results showed the great importance of the soil moisture factor combined with low light levels, for the expression of native forage potential yield. Indeed, the great importance of moderate shading levels to establish more adequate conditions for plant growth under silvopastoral systems in southern Brazil was evident.

The difference in DMY between the two evaluation cycles also reflected in different responses in the nitrogen status of plants. According to Gastal \& Lemaire (2009), the low soil water availability directly affects the mineral nutrition of plants by several mechanisms: (i) by reducing soil microbial activity and $\mathrm{N}$ mineralization and (ii) by reducing the transport of mineral $\mathrm{N}$ from soil to roots and the reduction of absorption capacity of the roots (Gastal \& Lemaire, 2009).

The relationships between forage production and herbage $\mathrm{N}$ content were presented in the form of dilution curves for each forage genotype and evaluation cycles (Figure 3). These curves, as described by Lemaire \& Gastal (2009), allowed the separation of actual nitrogen status of forages in two situations: when the points are above the critical $\mathrm{N}$ level, the plant is in great $\mathrm{N}$ consumption, and when they are below the critical curve, forages are in a deficiency of $\mathrm{N}$ supply.

In the dilution curves, in which data were determined for each of the three grasses (Figure 3), the dots representing the intense shading level (80\%), were near or just above the reference curve ( $\mathrm{N}$ critical level), showing that plants were in optimum herbage $\mathrm{N}$ condition. Under moderate shading (50\%), these points were in an intermediate position and those in full sunlight ( $0 \%$ shade) were far from the reference curve (Figure 3). This meant that the aerial biomass of grasses showed a better nitrogen status with increasing shade, i.e., it, there was increase of $\mathrm{N}$ levels per kg of dry matter in all grasses growing under shade compared with full sunlight.

The N dilution process in plant was clearly observed for the four genotypes studied (Figure 3), i.e., there was a decrease in the $\mathrm{N}$ content, as plant biomass was accumulated. According to the theory of $\mathrm{N}$ dilution (Greenwood et al., 1990), the decrease in the $\mathrm{N}$ concentration with plant growth was mainly due to an increase in the proportion of structural materials and storage tissues that contains little nitrogen, therefore the $\mathrm{N}$ concentration in the plant decreases.

In this study, $P$. regnellii and $P$. dilatatum (Figure $3 \mathrm{~A}$, $\mathrm{B}, \mathrm{C}$ and $\mathrm{D}$ ) showed $\mathrm{N}$ levels frequently close to or above the critical $\mathrm{N}$ level under $80 \%$ shade compared with moderate shade (50\%) and in full sunlight.

P. notatum had greater N (\%) in comparison with the other grasses. During the early growth stages, when initial DM forage mass was $2 \mathrm{t} / \mathrm{ha}$, it $\mathrm{N}$ values near to $2.5 \%$ were observed. At late growth stages, when average DMY were around 10-12 t/ha, herbage $\mathrm{N}$ content values were $1 \%$ (Figure 3 - and F). These values were similar to the $1.25 \%$ and 
0.09\% herbage $\mathrm{N}$ content observed in the early and late stages of growth, respectively. Likewise, $P$. regnellii and $P$. dilatatum (Figure 3A, B, C and D) showed similar values of $\mathrm{N}(\%)$ with mean levels ranging from $0.5 \%$ to $0.07 \% \mathrm{~N}$ in the early and late stages of plant growth, respectively.

The three grass genotypes grown under moderate shading had greater DMY, associated with higher levels of N (\%) per unit of biomass, compared with full sun. Thus, the grasses under the shade cloth showed a better nitrogen status in comparison with full sunlight. Since the critical N definition means the minimum amount of $\mathrm{N}$ required to achieve maximum plant growth rate, it could be implied that the moderate shade condition provided better growth environment for grasses than in full sunlight. On the other hand, the low solar irradiance available under heavy shade actually seemed to be the most limiting factor to use the available soil $\mathrm{N}$.
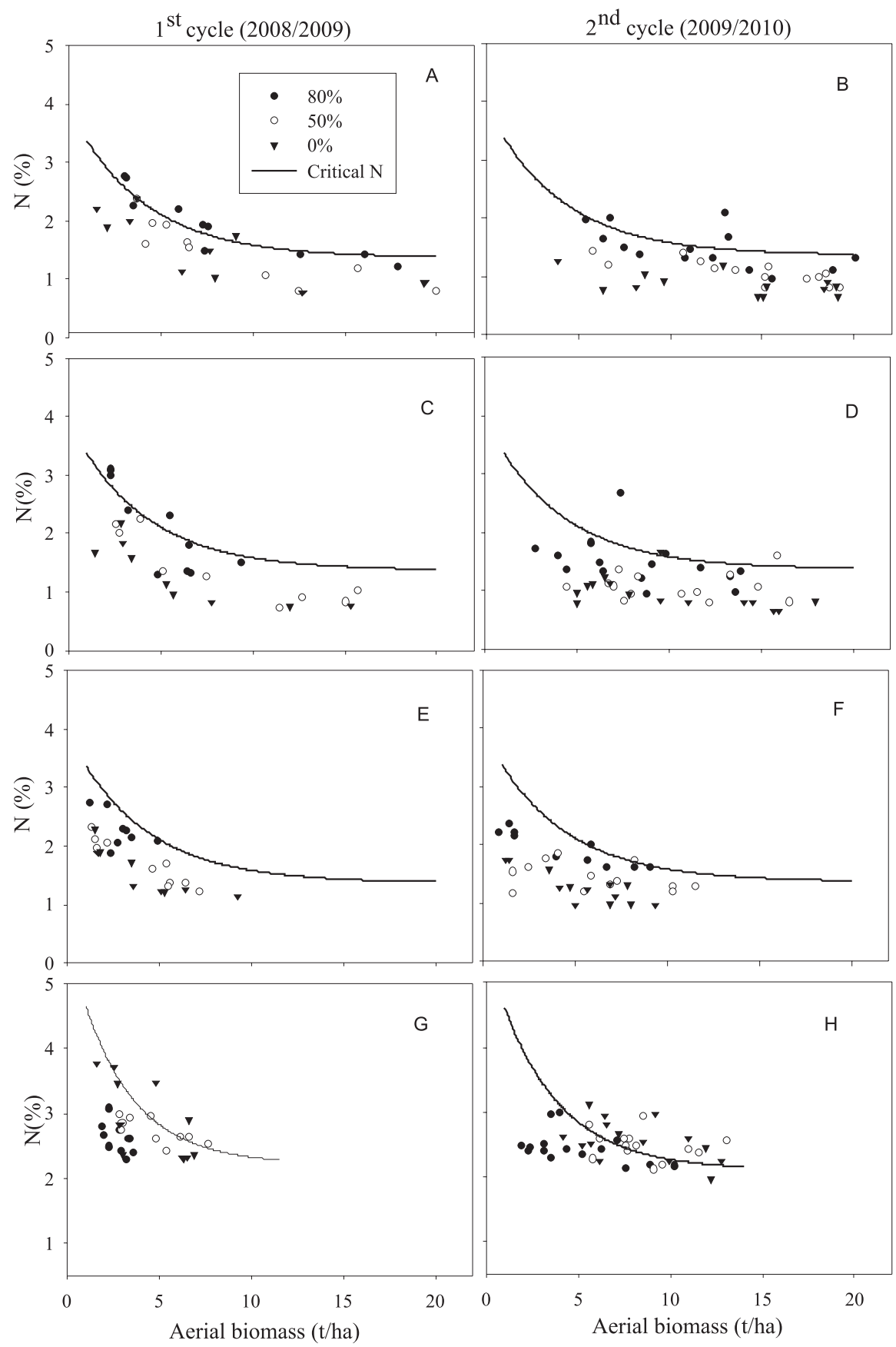

Reference curve: Nitrogen not limiting. Bagé, Rio Grande do Sul.

Figure 3 - N dilution curves in aerial biomass of Paspalum regnellii (A and B), Paspalum dilatatum (C and D), Paspalum notatum (E and F) and Arachis pintoi (G and H) over two evaluation cycles (2008/2009 and 2009/2010) in full sunlight ( $\boldsymbol{\nabla}$ ), under 50\% shading $(\bigcirc)$ and under $80 \%$ shading $(\bullet)$. 
The A. pintoi average $\mathrm{N}$ content was $2 \%$ in the early growth stage (Figure $3 \mathrm{G}$ and $3 \mathrm{H}$ ) and $0.3 \% \mathrm{~N}$ in late stages. The shading effect on plant nitrogen status of $A$. pintoi was contrasting to those observed for grasses, i.e., plants under shade showed lower $\mathrm{N}$ levels compared with plants in full sun. This result could be explained by a negative effect of shading on the nitrogen biological fixation process in roots, as well as by the reduction or suppression of plant root nodulation, thus decreasing forage DMY and plant $\mathrm{N}$ content, as suggested by Wong \&Wilson (1980).

In this study, where $\mathrm{N}$ soil fertilizer was applied at $100 \mathrm{~kg} / \mathrm{ha} /$ year, it was observed that nitrogen status of grasses growing under moderate and heavy shading was close or greater than the $\mathrm{N}$ critical level for maximum growth. The improvement of nitrogen nutrition of the grasses under shade was most evident in the first evaluation cycle (Table 2), when soil water deficit occurred. This result showed that adequate plant nitrogen nutrition status and growth under shade relied on a positive interaction between multiple factors, such as soil moisture and rate of nitrogen fertilization mainly.

On average, the three grasses had greater DMY associated with higher levels of $\mathrm{N}(\%)$ per unit of biomass (Table 2) under moderate shade (Table 1) compared with full sunlight. The legume showed a large reduction of $\mathrm{N}$ (\%) under the $80 \%$ shade level, indicating that $A$. pintoi was not suitable for heavy shaded environments, because it reduced both DMY $(\mathrm{P}<0.05)$ (Table 1$)$ and $\mathrm{N}$ content (Table 2) of the legume biomass, regardless of the soilwater availability.
The positive effects associated with the shade factor, such as the reduction of evaporative water demand, the maintenance of higher soil moisture content compared with full sun and its effects on plant nutrition has been discussed by other authors lately. Several studies conducted in Australia (Wilson \& Wild, 1991; Wilson \& Wild, 1995; Wilson, 1996), suggested that shaded environments per se should be considered the most critical single factor that leads to the so-called "shade effect". These studies also suggested that the "shade effect" occurs on tropical grasses, considering that gain in net photosynthesis is greater than the loss of photosynthetic potential activity, when the light level is reduced up to50\% compared with full sunlight. This usually occurred under $\mathrm{N}$-limiting conditions in Australian studies and it was observed that the response curve of most forage species was saturated at 50\% light (Wilson \& Wild, 1995).

In addition, several studies have confirmed an increase in the mineralization of soil organic matter rate by enhancing microbial activity, induced by appropriate temperatures and better water status in the topsoil, under artificial shade (Wilson, 1996). Thus, the increase of $\mathrm{N}$ availability in the soil could also be associated to the enhancement of plant growth under artificial shade compared with full sun.

Other studies have also reported increases in the forage yield of warm-season grasses both under artificial and natural shading (Stur, 1991; Cruz et al., 1995; Soares et al. 2009) and in most cases these results were also assigned to a higher availability of nitrogen in swards under shade compared with the full sun condition.

Table 2 - Mean values of nitrogen nutrition index (NNI\%) for Paspalum regnellii, Paspalum dilatatum, Paspalum notatum and Arachis pintoi under three shading levels (0\%, 50\%, 80\%) over two evaluation cycles (2008-2009 and 2009-2010)

\begin{tabular}{|c|c|c|c|c|c|}
\hline \multirow[t]{2}{*}{ Genotype } & \multirow[t]{2}{*}{ Shading level (\%) } & \multicolumn{2}{|c|}{$1^{\text {st }}$ cycle } & \multicolumn{2}{|c|}{$2^{\text {nd }}$ cycle } \\
\hline & & NNI (\%) & SE & NNI (\%) & SE \\
\hline \multirow[t]{4}{*}{ P. regnellii } & 0 & $75.0 \mathrm{~B}$ & 3.2 & $56.1 \mathrm{C}$ & 4.5 \\
\hline & 50 & $79.2 \mathrm{~B}$ & 3.2 & $72.5 \mathrm{~B}$ & 4.4 \\
\hline & 80 & $101.0 \mathrm{~A}$ & 3.2 & $92.1 \mathrm{~A}$ & 4.4 \\
\hline & Mean & 85.1 & & & 73.6 \\
\hline \multirow[t]{4}{*}{ P. dilatatum } & 0 & $58.6 \mathrm{~B}$ & 5.6 & $55.7 \mathrm{~B}$ & 7.8 \\
\hline & 50 & $78.7 \mathrm{AB}$ & 5.1 & $74.8 \mathrm{AB}$ & 7.8 \\
\hline & 80 & $93.7 \mathrm{~A}$ & 5.6 & $81.8 \mathrm{~A}$ & 7.8 \\
\hline & Mean & 77.0 & & & 70.7 \\
\hline \multirow[t]{4}{*}{ P. notatum } & 0 & $65.1 \mathrm{~B}$ & 2.6 & $64.5 \mathrm{~A}$ & 5.5 \\
\hline & 50 & $70.1 \mathrm{~B}$ & 2.2 & $72.3 \mathrm{~A}$ & 5.5 \\
\hline & 80 & $88.5 \mathrm{~A}$ & 2.4 & $81.6 \mathrm{~A}$ & 6.4 \\
\hline & Mean & 74.7 & & & 72.8 \\
\hline \multirow[t]{4}{*}{ A. pintoi } & 0 & $94.3 \mathrm{~A}$ & 4.6 & $102.6 \mathrm{~A}$ & 4.7 \\
\hline & 50 & $91.7 \mathrm{~A}$ & 4.6 & $101.5 \mathrm{~A}$ & 4.8 \\
\hline & 80 & $73.1 \mathrm{~B}$ & 4.9 & $82.2 \mathrm{~B}$ & 4.7 \\
\hline & Mean & 86.3 & & 95.4 & \\
\hline
\end{tabular}

Means followed by different capital letters in the columns for each genotype, differ by Tukey's test at 5\% significance level. SE - mean standard error. 


\section{Conclusions}

The plant growth under moderate shading (50\%) had a positive effect on the dry matter yield of grasses. However, the heavy shading (80\%) negatively affected forage yield of all genotypes. Paspalum regnellii had high potential for utilization under shaded environments ranging from moderate to heavy shading. This genotype, along with Paspalum dilatatum, showed the highest potential yield under intermediate shading. The increase on shading enhanced the level of nitrogen nutrition status of grass genotypes, which also led to improvements of forage quality. The nitrogen status of Arachis pintoi was always reduced by all shading levels. All genotypes showed to be promising for use in silvopastoral systems as understory components, especially under moderate shade conditions in the Campanha Region of the state of Rio Grande do Sul, in southern Brazil.

\section{Acknowledgments}

Special thanks are due to Prof. Don M. Ball, Dept. of Agronomy and Soils (Forage Crops), Auburn University, AL, USA, for his in-depth review and contributions made to the manuscript.

\section{References}

ANDRADE, C.M.S.; VALENTIM, J.F. Adaptação, produtividade e persistência de Arachis pintoi submetido a diferentes níveis de sombreamento. Revista Brasileira de Zootecnia, v.28, n.3, p.439-445, 1999.

ASSOCIATION OF OFFICIAL ANNALYTICAL CHEMISTS - AOAC. Official methods of analysis. 12.ed. Washington, 1975. 1094p.

BARRO, R.S.; VARELLA, A.C.; BANGEL, F.V. et al. Screening native C4 pasture genotypes for shade tolerance in Southern Brazil. In: AUSTRALIAN SOCIETY OF AGRONOMY CONFERENCE, 15., 2010, Lincoln. Proceedings... Lincoln, 2010. p.1-5.

CRUZ, P.; TOURNEBIZE, R.; GAUDICHAU, C. et al. Effect of shade on growth, nitrogen content and $\mathrm{CO} 2$ leaf assimilation in a tropical perennial grass. In: The ecophysiology of tropical intercropping. SINOQUET, H.; CRUZ, P. (Eds.). Paris: INRA Editions, 1995. p.285-293.

GOBBI, K.F.; GARCIA, R., GARCEZ NETO, A.F. et al. Características morfológicas, estruturais e produtividade do capim-braquiária e do amendoim forrageiro submetidos ao sombreamento. Revista Brasileira de Zootecnia, v.38, p.1645-1654. 2009.

GREenWOOD, D.J.; LEMAIRE, G.; GOSSE, G. et al. Decline in percentage $\mathrm{N}$ of $\mathrm{C} 3$ and $\mathrm{C} 4$ crops with increasing plant mass. Annals of Botany, v.66, p.425-436, 1990.

LEMAIRE, G.; GASTAL, F. N uptake and distribution in plant canopies. In: LEMAIRE G. (Ed.) Diagnosis of nitrogen status in crops. Heidelberg: Springer-Verlag, 1997. p.3-43.
LEMAIRE, G.; GASTAL, F. Quantifying crop responses to nitrogen deficiency and avenues to improve nitrogen use efficiency. In: SADRAS, V.O.; CALDERINI, D.F. (Eds.) Crop Physiology. Applications for genetic improvement and agronomy. Adelaide: Academic Press; Elsevier, 2009. p.171-199.

LUDWIG, F.; DE KROON, H.; PRINS, H.H.T. et al. The effect of nutrients and shade on tree grass interactions on an East African savanna. Journal of Vegetation Science, v.12, p.579-588. 2001.

RAMOS, A.M.; SANTOS, L.A.; FORTES, L.T.G. Normais climatológicas do Brasil 1961-1990. Brasília: INMET, 2009. 465p.

RAMOS A.K.B.; BARCELLOS A.O.; FERNANDES F.D. Gênero Arachis. In: FONSECA, D.M.; MARTUSCELlO, J.A. (Eds.) Plantas forrageiras. Viçosa, MG: Editora da UFV, 2010. p.249-293.

SAIBRO, J.C. Animal production from tree-pasture association systems in Brazil. In: INTERNATIONAL GRASSLAND CONGRESS, 19., 2001, São Pedro. Anais... São Pedro: FEALQ, 2001. p.637-643.

SOARES, A.B.; SARTOR, L.R.; ADAMI, P.F. et al. Influência da luminosidade no comportamento de onze espécies forrageiras perenes de verão. Revista Brasileira de Zootecnia, v.38, p.443-451, 2009.

SOCIEDADE BRASILEIRA DE CIÊNCIA DO SOLO - SBCS. Manual de adubação e calagem para os Estados do Rio Grande do Sul e de Santa Catarina. 10.ed. Porto Alegre, 2004. 400p.

STRECK, E.V.; KÄMPF, N.; DALMOLIN, R.S.D. et al. Solos do Rio Grande do Sul. 2.ed. Porto Alegre: Emater/RS, 2008. 222p.

STÜR, W. Screening forage species for shade tolerance-a preliminary report. In: SHELTON, H.M.; STÜR, W.W. (Eds.). Forages for plantation crops. Canberra: Australian Centre for International Agricultural Research, 1991. p.58-63.

VALLS, J.M.F.; BOLDRINI, I.I.; LONGHI-VAGNER, H.M. et al. O patrimônio florístico dos Campos: potencialidades de uso e a conservação de seus recursos genéticos In: PILLAR, V.D.; MULLER, S.C.; CASTILhOS, Z.M.S. et al. (Eds.) Campos Sulinos, conservação e uso sustentável da biodiversidade. Brasília, 2009. p.139-154.

VARELLA, A.C.; SILVA, V.P.; SOARES, A.B. et al. Screening native and cultivated tropical pastures for silvipastoral systems in Southern Brazil. In: CONGRESSO NACIONAL DE SISTEMAS SILVOPASTORILES, 2009, Posadas. ACTAS... BUENOS AIRES: INTA, 2009. v.1, p.363-367.

WILSON, J.R.; WILD, D.W.M. Improvement of nitrogen nutrition and grass growth under shading. In: SHELTON, H.M.; STÜR, W.W. (Eds.) Forages for plantation crops. Canberra, Australia: ACIAR, 1991. p.77. (ACIAR Proceedings, 32).

WILSON J.R.; WILD D.W.M. Nitrogen availability and grass yield under shade environments. In: MULLEN, B.F.; SHELTON, H.M. (Eds.) Integration of ruminants into plantations systems in Southeast Asia. Canberra, Austrália: ACIAR, 1995. p.42-48. (ACIAR Proceedings, 64).

WILSON, J.R.; HILL, K.; CAMERON, D.M.; SHELTON, H.M. The growth of Paspalum notatum under the shade of a Eucalyptus grandis plantation canopy or in full sun. Tropical Grassland, v.24, p.24-28, 1990.

WILSON, J.R. Shade-stimulated growth and nitrogen uptake by pastures grasses in a subtropical environment. Australian Journal of Agricultural Research, v.47, p.1075-1093, 1996.

WILSON, J.R.; WONG, C.C. Effects of shade on some factors influencing nutritive quality of green panic and siratro pastures. Australian Journal of Agricultural Research, v.33, n.6, p.937-949, 1982.

WONG, C.C.; WILSON, J.R. The effect of shade on the growth and nitrogen content of green panic and siratro in pure and mixed swards defoliated at two frequencies. Australian Journal of Agricultural Research, v.31, p.269-285, 1980. 